\title{
Perspectives \\ Welcoming low testosterone as a cardiovascular risk factor
}

\author{
$\mathrm{M} \mathrm{Maggio}^{1}$ and S Basaria ${ }^{2}$ \\ ${ }^{1}$ Department of Internal Medicine, Division of Endocrinology \& Metabolism, University of Parma, Parma, Italy and \\ ${ }^{2}$ Department of Internal Medicine, Division of Endocrinology \& Metabolism, Boston University School of Medicine, \\ Boston, MA, USA
}

\begin{abstract}
Male hypogonadism now has a new spectrum of complications. They are mainly cardiometabolic in nature. Low serum testosterone levels are a risk factor for diabetes, metabolic syndrome, inflammation and dyslipidemia. These metabolic and inflammatory complications are not without consequences. Recent studies have shown low serum testosterone levels to be an independent risk factor of cardiovascular and all-cause mortality. It is time to welcome low serum testosterone levels as a cardiovascular risk factor.
\end{abstract}

International Journal of Impotence Research (2009) 21, 261-264; doi:10.1038/ijir.2009.25;

published online 18 June 2009

Keywords: hypogonadism; metabolic syndrome; diabetes; inflammation

Testosterone is the predominant sex hormone in man. A young man produces 3-10 mg of testosterone daily that results in serum levels of 300-1000 ng per $100 \mathrm{ml}$. The traditional consequences of male hypogonadism are well known. These include decreased libido, erectile dysfunction, decreased muscle mass and strength, increased fat mass, changes in mood and energy, osteoporosis and decreased sexual hair. ${ }^{1}$ However, for the past two decades, many studies have found an association between low serum testosterone levels and various cardiovascular (CV) risk factors. In addition, some epidemiological studies have also linked low testosterone levels with CV and all-cause mortality. In this review, we will briefly touch upon the various CV risk factors that have been linked to low serum testosterone in men.

\section{Diabetes and metabolic syndrome}

Low testosterone levels have been associated with diabetes and metabolic syndrome. Epidemiological studies have reported that low testosterone levels

Correspondence: Professor S Basaria, Androgen Clinical Research Unit, Division of Endocrinology \& Metabolism, Boston University School of Medicine, Boston Medical Center, 670 Albany Street, 2nd Floor, Boston, MA 02118, USA.

E-mail: shehzad.basaria@bmc.org

Received 2 April 2009; revised 11 May 2009; accepted 12 May 2009; published online 18 June 2009 are an independent risk factor for type-2 diabetes. ${ }^{2}$ Interestingly, concentrations of free and bioavailable testosterone even in the low-normal range are associated with diabetes, after adjusting for adiposity. $^{3}$ Similarly, low total testosterone levels independently predict development of the metabolic syndrome in middle-aged men. ${ }^{4}$ Interventional trials have shown that testosterone administration results in an increased glucose uptake by the muscles, thereby improving insulin sensitivity. ${ }^{5}$ One study even showed an improvement in HbA1c in hypogonadal men with type-2 diabetes who received testosterone. ${ }^{6}$ Another study showed that testosterone replacement inhibits incorporation of triglycerides in visceral fat (which is the most active depot metabolically and contributes to insulin resistance). ${ }^{7}$ In addition, androgen deprivation in men with prostate cancer is associated with hyperglycemia and metabolic syndrome, ${ }^{8,9}$ and the degree of hyperglycemia is directly related to the duration of castration. ${ }^{10}$ Thus, even low-normal levels of testosterone appear to be a risk factor for metabolic dysregulation.

\section{Hyperlipidemia and inflammation}

In contrast to the belief of many physicians that androgen administration leads to an adverse lipid profile, research shows that physiological testosterone replacement is at least neutral (if not beneficial) to lipids. Hence, it should be differentiated from non-aromatizable androgens that do result in harm- 
ful lipid profile by lowering high-density lipoprotein. Epidemiological data suggest that testosterone levels are associated negatively with total cholesterol, low-density lipoprotein cholesterol and triglycerides, and positively with high-density lipoprotein cholesterol. ${ }^{11}$ Trials of testosterone replacement have shown an improvement in lipid profile. ${ }^{12}$ Similarly, there are reports of inverse associations between inflammatory cytokines and testosterone, ${ }^{13}$ and a reduction in these cytokines is seen with testosterone replacement. ${ }^{12}$ Furthermore, inverse associations have been found between testosterone and plasminogen activator inhibitor I, fibrinogen and factor VII. ${ }^{14}$

\section{Atherosclerosis}

Studies show that low testosterone levels are associated with atherosclerosis in all major vessels. Animal experiments have shown that testosterone inhibits plaque development in rabbits and rodents fed a high-fat diet. ${ }^{15}$ It was Phillips et al. ${ }^{16}$ who first reported an inverse relationship between low total and free testosterone levels and angiographically proven coronary artery disease after adjusting for age and adiposity. A recent study confirmed these findings, showing that men with coronary artery disease had lower levels of testosterone than controls and that testosterone levels were inversely correlated to the degree of coronary atherosclerosis. ${ }^{17}$ In the Rotterdam study, the association between total and bioavailable testosterone and aortic atherosclerosis was evaluated in 504 nonsmoking men aged $\geqslant 55$ years. ${ }^{14}$ They found that men in the highest tertile had a risk reduction of 60 $80 \%$ of severe aortic atherosclerosis after controlling for age and CV risk factors. Another prospective study of elderly men (mean age 77 years) showed free testosterone to be inversely related to the progression of intima-media thickness of the common carotid artery over 4 years. ${ }^{18}$ Furthermore, men in the lowest tertile of testosterone experienced more progression.

\section{Vascular tone and endothelial function}

The vascular system is a target of androgen action and current evidence suggests that androgens are beneficial to vasculature. Older studies conducted more than six decades ago showed that testosterone replacement relieved symptoms of angina and peripheral vascular disease. ${ }^{19}$ Similarly, population studies have shown that systolic and diastolic blood pressures are inversely correlated with testosterone. ${ }^{20}$ Recent animal studies show that acute treatment with testosterone results in dilatation of the coronary and pulmonary arteries. ${ }^{21}$ In humans,

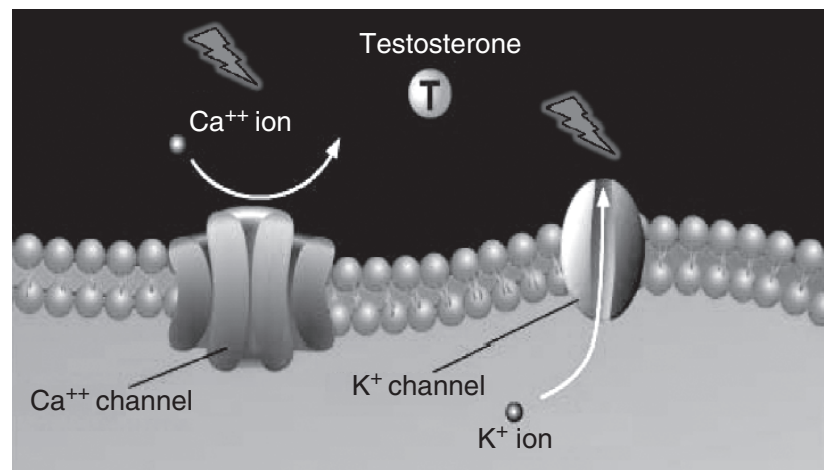

Figure 1 Action of testosterone on calcium and potassium channels.

transdermal testosterone therapy improves exerciseinduced myocardial ischemia (measured as time to ST depression) during an exercise stress test in men with stable angina, ${ }^{22}$ with men having the lowest baseline testosterone levels benefitting the most. A recent study using oral testosterone in hypogonadal men with coronary artery disease showed increased myocardial perfusion. ${ }^{23}$ These vasodilatory effects of testosterone are reflected by the fact that men with prostate cancer undergoing androgen deprivation therapy experience arterial stiffness. ${ }^{24}$ It is believed that testosterone causes both endothelium-dependent and endothelium-independent vasodilation. The former is achieved by an increased release of nitric oxide from endothelium, whereas the latter by blocking of calcium channels and/or opening of potassium channels ${ }^{25}$ (Figure 1). Recent studies also suggest a beneficial role for testosterone in endothelial regeneration. ${ }^{26}$ Testosterone replacement in hypogonadal men results in an increase in the number of circulating endothelial progenitor cells. ${ }^{27}$ This increase is androgen receptor mediated (not a result of rise in estrogen levels) as this event is abolished by androgen receptor antagonists. ${ }^{28}$

\section{Mortality}

Recent population studies have shown that low serum testosterone levels are associated with both $\mathrm{CV}$ and all-cause mortality. A retrospective study of male veterans showed that low testosterone was associated with increased mortality. ${ }^{29}$ A prospective study of 794 men, aged 50-91 years, looked at the relationship of testosterone with all-cause mortality over two decades. ${ }^{30}$ Men with total testosterone levels in the lowest quartile $(<241 \mathrm{ng}$ per $100 \mathrm{ml})$ were $40 \%$ more likely to die than men with higher androgen levels, independent of age, adiposity, lipids, adipokines and lifestyle. In cause-specific analyses, low testosterone predicted increased risk 


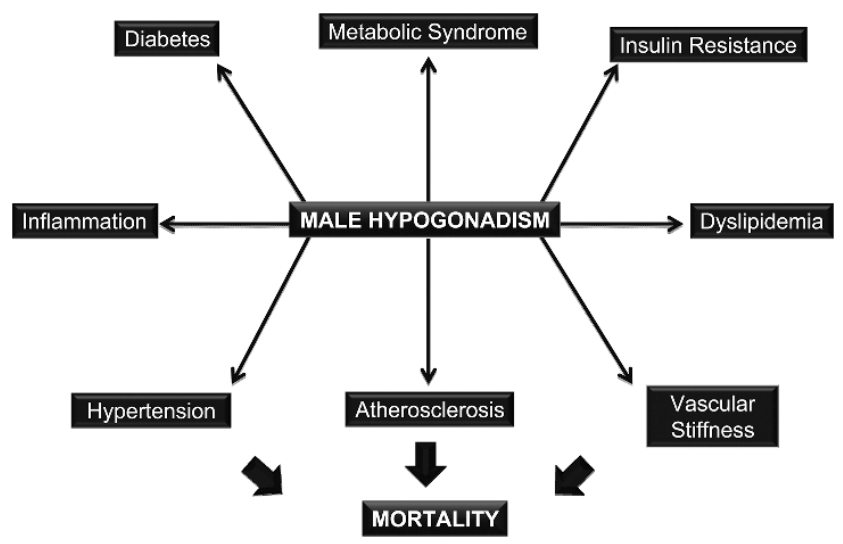

Figure 2 New spectrum of CV complications of low testosterone levels. CV, cardiovascular.

of mortality due to CV and respiratory disease. In a recent study, Khaw et al. ${ }^{31}$ conducted a nested casecontrol study to determine the association of endogenous serum testosterone with all-cause, CV and cancer-related mortality. The authors compared 825 men who did not have any CV disease or cancer at baseline but died during the course of follow-up, with 1489 men who were still alive. The cases and controls were matched for age and date of baseline visit. The authors found that baseline testosterone levels were inversely related to deaths due to all cause, CV disease and malignancy. This protective effect of testosterone increased with increasing quartiles such that men in the highest quartile had $30 \%$ lower risk of death compared with those in the lowest quartile. Similarly, men undergoing androgen deprivation therapy for prostate cancer are also at risk of increased $\mathrm{CV}$ mortality compared with men not undergoing castration. ${ }^{32}$

\section{Conclusion}

This review shows that ample evidence has accumulated through epidemiological studies and small clinical trials showing that low androgen levels are associated with numerous CV risk factors and mortality (Figure 2). In addition to traditional CV risk factors, novel risk factors are also inversely related to testosterone levels. Indeed, a recent study showed that low testosterone levels increase oxidative stress in men and testosterone replacement reverses this pathology. ${ }^{33}$ Similarly, the effect of testosterone treatment in men with chronic heart failure is also being explored. ${ }^{34}$ Now what we need are long-term, double-blind, randomized, placebocontrolled trials of androgen replacement in men with low testosterone levels and evaluate its effect on $\mathrm{CV}$ risk factors, CV mortality and all-cause mortality. What we need is a Men's Health Initiative study and the federal funding agencies should be
Low testosterone as a cardiovascular risk factor M Maggio and S Basaria

open to this kind of trial. In the meantime, we should consider welcoming low testosterone as a new CV risk factor in men.

\section{Conflict of interest}

The authors declare no conflict of interest.

\section{References}

1 Basaria S, Dobs AS. Hypogonadism and androgen replacement therapy in elderly men. Am J Med 2001; 110: 563-572.

2 Stellato RK, Feldman HA, Hamdy O, Horton ES, McKinlay JB. Testosterone, sex hormone-binding globulin, and the development of type 2 diabetes in middle-aged men: prospective results from the Massachusetts male aging study. Diabetes Care 2000; 23: 490-494.

3 Selvin E, Feinleib M, Zhang L, Rohrmann S, Rifai N, Nelson WG et al. Androgens and diabetes in men: results from the Third National Health and Nutrition Examination Survey (NHANES III). Diabetes Care 2007; 30: 234-238.

4 Laaksonen DE, Niskanen L, Punnonen K, Nyyssonen K, Tuomainen TP, Valkonen VP et al. Testosterone and sex hormone-binding globulin predict the metabolic syndrome and diabetes in middle-aged men. Diabetes Care 2004; 27: 1036-1041.

5 Marin P, Holmang S, Jonsson L, Sjostrom L, Kvist H, Holm G et al. The effects of testosterone treatment on body composition and metabolism in middle-aged obese men. Int $J$ Obes Relat Metab Disord 1992; 16: 991-997.

6 Boyanov MA, Boneva Z, Christov VG. Testosteone supplementation in men with type 2 diabetes, visceral obesity and partial androgen deficiency. Aging Male 2003; 6: 1-7.

7 Marin P, Lonn L, Andersson B, Oden B, Olbe L, Bengtsson BA et al. Assimilation of triglycerides in subcutaneous and intraabdominal adipose tissues in vivo in men: effects of testosterone. I Clin Endocrinol Metab 1996; 81: 1018-1022.

8 Basaria S, Muller DC, Carducci MA, Egan J, Dobs AS. Hyperglycemia and insulin resistance in men with prostate carcinoma who receive androgen-deprivation therapy. Cancer 2006; 106: 581-588.

9 Braga-Basaria M, Dobs AS, Muller DC, Carducci MA, John M, Egan J et al. Metabolic syndrome in men with prostate cancer undergoing long-term androgen-deprivation therapy. J Clin Oncol 2006; 24: 3979-3983.

10 Basaria S, Muller DC, Carducci MA, Egan J, Dobs AS. Relation between duration of androgen deprivation therapy and degree of insulin resistance in men with prostate cancer. Arch Intern Med 2007; 167: 612-613.

11 Haffner SM, Mykkanen L, Valdez RA, Katz MS. Relationship of sex hormones to lipids and lipoproteins in nondiabetic men. J Clin Endocrinol Metab 1993; 77: 1610-1615.

12 Malkin CJ, Pugh PJ, Jones RD, Kapoor D, Channer KS, Jones TH. The effect of testosterone replacement on endogenous inflammatory cytokines and lipid profiles in hypogonadal men. J Clin Endocrinol Metab 2004; 89: 3313-3318.

13 Maggio M, Basaria S, Ble A, Lauretani F, Bandinelli S, Ceda GP et al. Correlation between testosterone and the inflammatory marker soluble interleukin-6 receptor in older men. J Clin Endocrinol Metab 2006; 91: 345-347.

14 Hak AE, Witteman JC, de Jong FH, Geerlings MI, Hofman A, Pols HA. Low levels of endogenous androgens increase the risk of atherosclerosis in elderly men: the Rotterdam study. I Clin Endocrinol Metab 2002; 87: 3632-3639.

15 Hanke H, Lenz C, Hess B, Spindler KD, Weidemann W. Effect of testosterone on plaque development and androgen receptor expression in the arterial vessel wall. Circulation 2001; 103: $1382-1385$. 
16 Phillips GB, Pinkernell BH, Jing TY. The association of hypotestosteronemia with coronary artery disease in men. Arterioscler Thromb 1994; 14: 701-706.

17 Rosano GM, Sheiban I, Massaro R, Pagnotta P, Marazzi G, Vitale $\mathrm{C}$ et al. Low testosterone levels are associated with coronary artery disease in male patients with angina. Int $J$ Impot Res 2007; 19: 176-182.

18 Muller M, van den Beld AW, Bots ML, Grobbee DE, Lamberts SW, van der Schouw YT. Endogenous sex hormones and progression of carotid atherosclerosis in elderly men. Circulation 2004; 109: 2074-2079.

19 Lesser MA. Testosterone propionate therapy in one hundred cases of angina pectoris. I Clin Endocrinol Metab 1946; 6: 549-557.

20 Khaw KT, Barrett-Connor E. Blood pressure and endogenous testosterone in men: an inverse relationship. J Hypertens 1988; 6: $329-332$.

21 Chou TM, Sudhir K, Hutchison SJ, Ko E, Amidon TM, Collins $\mathrm{P}$ et al. Testosterone induces dilation of canine coronary conductance and resistance arteries in vivo. Circulation 1996; 94: 2614-2619.

22 English KM, Steeds RP, Jones TH, Diver MJ, Channer KS. Low-dose transdermal testosterone therapy improves angina threshold in men with chronic stable angina: a randomized, double-blind, placebo-controlled study. Circulation 2000; 102: 1906-1911.

23 Webb CM, Elkington AG, Kraidly MM, Keenan N, Pennell DJ, Collins P. Effects of oral testosterone treatment on myocardial perfusion and vascular function in men with low plasma testosterone and coronary artery disease. Am J Cardiol 2008; 101: $618-624$.

24 Smith JC, Bennett S, Evans LM, Kynaston HG, Parmar M, Mason MD et al. The effects of induced hypogonadism on arterial stiffness, body composition, and metabolic parameters in males with prostate cancer. J Clin Endocrinol Metab 2001; 86: 4261-4267.

25 Jones RD, Pugh PJ, Jones TH, Channer KS. The vasodilatory action of testosterone: a potassium-channel opening or a calcium antagonistic action? Br J Pharmacol 2003; 138: 733-744.

26 Traish AM, Saad F, Feeley RJ, Guay AT. The Dark Side of Testosterone Deficiency: III. Cardiovascular Disease. J Androl 2009 (e-pub ahead of print).

27 Foresta C, Caretta N, Lana A, De Toni L, Biagioli A, Ferlin A et al. Reduced number of circulating endothelial progenitor cells in hypogonadal men. J Clin Endocrinol Metab 2006; 91: 4599-4602.

28 Foresta C, Zuccarello D, De Toni L, Garolla A, Caretta N, Ferlin A. Androgens stimulate endothelial progenitor cells through an androgen receptor-mediated pathway. Clin Endocrinol (Oxf) 2008; 68: 284-289.

29 Shores MM, Matsumoto AM, Sloan KL, Kivlahan DR. Low serum testosterone and mortality in male veterans. Arch Intern Med 2006; 166: 1660-1665.

30 Laughlin GA, Barrett-Connor E, Bergstrom J. Low serum testosterone and mortality in older men. J Clin Endocrinol Metab 2008; 93: 68-75.

31 Khaw K-T, Dowsett M, Folkerd E, Bingham S, Wareham N, Luben $\mathrm{R}$ et al. Endogenous testosterone and mortality from all causes, CV disease and cancer in men: EPIC-Norfolk prospective population study. Circulation 2007; 116: 2694-2701.

32 Keating NL, O’Malley AJ, Smith MR. Diabetes and cardiovascular disease during androgen deprivation therapy for prostate cancer. J Clin Oncol 2006; 24: 4448-4456.

33 Mancini A, Leone E, Festa R, Grande G, Silvestrini A, de Marinis L et al. Effects of testosterone on antioxidant systems in male secondary hypogonadism. J Androl 2008; 29: 622-629.

34 Malkin CJ, Jones TH, Channer KS. Testosterone in chronic heart failure. Front Horm Res 2008; 37: 183-196. 